\title{
Removal of Nitrate from Ground Water Using Neem Leaves as Adsorbent
}

\author{
Gowtham Balasundaram ${ }^{1}$, Dr Ananthasingh T.S ${ }^{2}$, and Dr Anuragkandya ${ }^{3}$
}

\begin{abstract}
Groundwater serves a major source of water for drinking and other domestic purposes in the Vadodara district of India. Due to the rapid industrialisation and exceeded use of chemical fertilisers, Nitrate levels in the ground water were found to be $64.5 \mathrm{mg} / \mathrm{l}$ which is much higher than the permissible limits. Of available techniques adsorption using Neem leaves powder was found to be efficient and cost friendly method for removal of Nitrate ions from water. Studies revealed that the maximum nitrate removal efficiency was obtained using batch adsorption studies conducted for a reaction time of $40 \mathrm{~min}$ using $0.5 \mathrm{~g}$ adsorbent per $100 \mathrm{ml}$ of the water sample. Optimization of process parameters such as reaction time, adsorbent dosage, $\mathrm{pH}$, temperature were also studies to find out the maximum removal efficiency.
\end{abstract}

Keywords - Adsorption, Efficiency, Groundwater, Nitrate.

\section{INTRODUCTION}

$\mathrm{W}$ ater is most important component of the earth's surface. In India, most of the population is dependent on ground water as the source of drinking water supply.[1] Though $23,400,000 \mathrm{~km} 3$ of ground water is available on earth, due to the increased human population, urbanisation, increased use of fertilizers the ground water quality has deteriorated in the recent years greatly.[2] In developing countries like India around $80 \%$ of all diseases are directly related to poor drinking water quality and unhygienic conditions.[3].

Nitrate contamination in ground and drinking water caused serious concerns in the recent days. In the last decade, nitrate concentration has increased both in ground and surface water at a rapid rate.[4]

The increasing use of nitrogen fertilizers in agriculture sector is the reason for the contamination caused by nitrate. Other factors such as sewage, urban and agricultural runoffs, leachate, untreated wastewater disposal, industrial wastewater, septic system, waste disposal site leachate, agricultural

Gowtham Balasundaram1, Pandit Deendayal Petroleum University, Gandhinagar-382007 (Phone no.+91-8141178913, email:gowthambswamy@gmail.com

Dr. AnanthSingh T.S2, Assistant Professor, Pandit Deendayal Petroleum University, Gandhinagar-382007 (e-mail: anantha.singh@sot.pdpu.ac.in)

Dr. Anurag kandya, Assistant Professor, Pandit Deendayal Petroleum University, Gandhinagar-382007 (e-mail: akandya@gmail.com). fertilizer, and nitrogen compounds added to the air through industry and cars also give rise to the pollutants in waters. Due to its high solubility and sustainability, removal of nitrate from drinking water has turned into a challenging duty to researchers]Many physical, chemical, and biological methods are used to remove nitrate from drinking water, namely chemical denitrification process using zero capacity iron, ion exchange, reverse osmosis, electro dialysis, and biological denitrification. Among other technologies used for water treatment, the adsorption process is in general low-cost, simply designed, as it is identified as an easy applicable technique.[5] This paper details the batch adsorption technique for removal of Nitrate from ground water using Neem leaves as adsorbent which is discussed further below..

\section{MATERIALS AND METHODS}

\section{A. Study Area}

Vadodara district with $7548.50 \mathrm{Sq} \mathrm{km}$ area, is located central part of mainland Gujarat, lies between $21^{\circ} 49^{\circ e} 19^{\prime \prime}$ and $22^{\circ} 48^{\circ e} 37^{\prime \prime}$ north latitude and $72^{\circ} 51^{\circ e} 05^{\prime}$ 'and $74^{\circ} 16^{\circ e} 55^{\prime \prime}$ east longitude. The district is bounded in north \& northeast by Anand, Panchmahals \& Dahod districts, in east \& in south east by Madhya Pradesh\& Maharashtra State, in south east by Narmada district $\&$ in south $\&$ in west by Bharuch district.

\section{B. Sample Collection and Preservation}

Ground water sample was collected from a bore well near the Vadodara railway station. Samples were kept in an ice cooled container and taken to PDPU, Environmental engineering laboratory for analysis. They were stored in refrigerator at a temperature of $4^{\circ} \mathrm{C}$ during the study time.

\section{C.Preparation OfAdsorbent}

Neem leaves collected from residential area were cleaned and dried under sun for 7 days. The dried leaves were ground to powder and sieved. The powder on the mesh of sizes of $300 \mu \mathrm{m}$ and $150 \mu \mathrm{m}$ was collected separately. Neem powder was washed thoroughly and dried and stored in bottle as adsorbent for the study.

\section{D.Preparation Of Nitrate Sample}

Anhydrous and pure Potassium Nitrate (KNO3) was used as a source of nitrate. All experiments were carried with water sample of $100 \mathrm{mg} / \mathrm{l}$ nitrate concentration which was prepared 
by dissolving nearly $0.0728 \mathrm{~g}$ of $\mathrm{KNO} 3$ in $100 \mathrm{ml}$ of distilled water.

\section{E. Calibration Of Standard Nitrate Curve}

Stock solution of nitrate concentration $10 \mathrm{mg} / \mathrm{l}$ was prepared and it is diluted to obtain nitrate concentrations of $0,1,2,4,6,8,10$ $\mathrm{mg} / \mathrm{l}$. The absorbance values were taken at a wavelength of 220 $\mathrm{nm}$ in UV-Visible spectrophotometer and a graph of absorbance and nitrate concentration was drawn. This was taken as standard curve and used for the entire study to detect nitrate in the ground water after adsorption.

\section{F. Detection of Nitrate}

The solutions of all the above experiments were filtered and diluted to bring them into the concentration range of standard curve. The absorbance of diluted sample was taken at $220 \mathrm{~nm}$ in UV-Visible spectrophotometer. The concentration corresponding to the measured absorbance was read from the standard curve and removal efficiency was found out using the equation

Removal Efficiency $=(\mathrm{C} 0-\mathrm{C} 1) / \mathrm{C} 0)^{*} 100$

Where, $\mathrm{C} 0=$ Initial nitrate concentration, $\mathrm{C} 1=$ Nitrate concentration in water after adsorption.

\section{G, Effect Of Contact Time}

$0.1 \mathrm{~g}$ of adsorbent was taken in $100 \mathrm{ml}$ of nitrate sample and was allowed for stirring for different time periods of 5,10, $15,20,25,30,60,90,120$ and $180 \mathrm{~min}$ at a speed of $120 \mathrm{rpm}$ on an orbital shaker. The solution is filtered and adsorbent is separated from the treated nitrate sample.

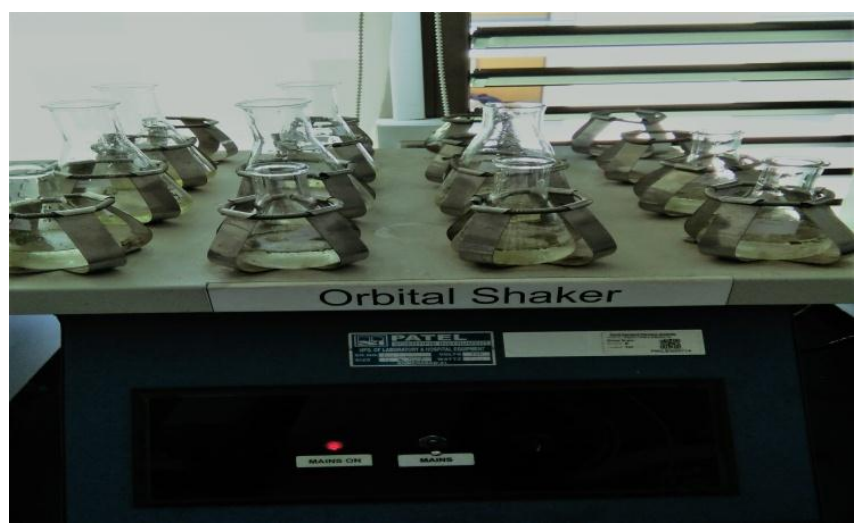

Fig 1 Batch Adsorption Studies

\section{H.Effect Of Adsorbent Dosage}

The effect of adsorbent dosage was studied by varying adsorbent weight at $0.025,0.05,0.1,0.15,0.2,0.25,0.3,0.35,0.4$, $0.45,0.5 \mathrm{~g}$ of adsorbent in nitrate sample and allowed for stirring for a duration of $40 \mathrm{mins}$ and $50 \mathrm{mins}$ respectively.

\section{RESULTS AND DISCUSSIONS}

\section{A. Standard Nitrate Calibration Curve}

Stock solution of $1 \mathrm{mg} / 1,2 \mathrm{mg} / 1,4 \mathrm{mg} / 1,6 \mathrm{mg} / 1,8 \mathrm{mg} / 1,10 \mathrm{mg} / 1$ of nitrate was prepared for $\neg$ calibration of standard curve. Standard nitrate curve is given below

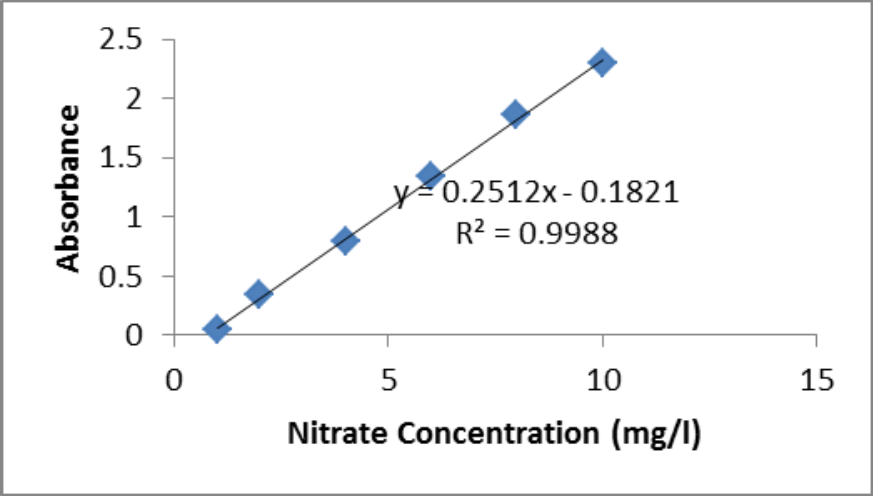

Fig2 Standard Nitrate Curve

It was found that the Nitrate Concentration was $64.5 \mathrm{mg} / \mathrm{l}$ which was found to be higher than the permissible limits prescribed by Indian Standards.

\section{B. Effect Of Contact Time}

The effect of contact time on removal efficiency was studied at $0 \mathrm{~min}$, 5min, 10min, 15min, 25min, 30min, 60min, 90min, $120 \mathrm{~min}, 180 \mathrm{~min}$. The highest efficiency of nearly $68 \%$ was observed for contact time of $180 \mathrm{~min}$ when $0.1 \mathrm{~g}$ of adsorbent with a size fraction of 300microns was used. However the removal efficiency for contact time after 50min was also nearly the same. Hence Contact time of 50min was selected as optimum contact time and used for all the other experiments .

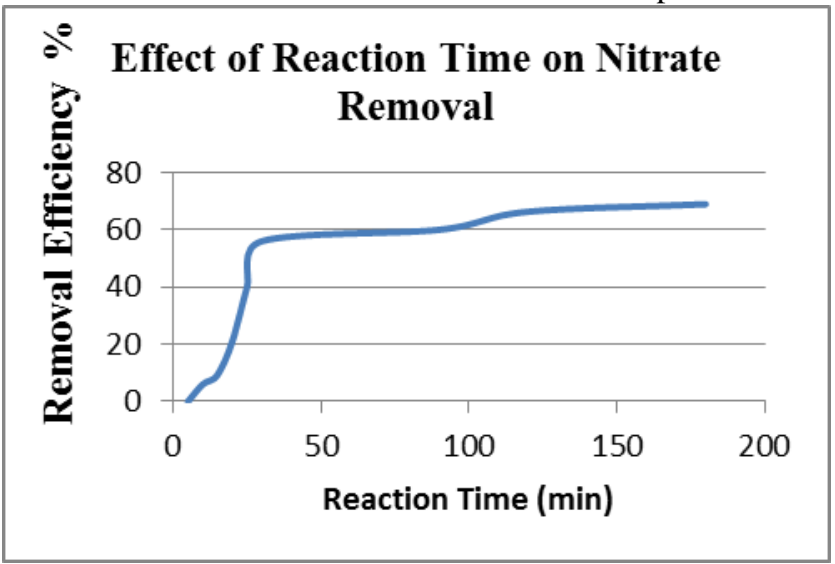

Fig 3 Effect of Reaction Time on Adsorption

\section{Effect OfAdsorbent Dosage}

The effect of adsorbent dosage on removal efficiency was studied using $0.05 \mathrm{~g}, 0.1 \mathrm{~g}, 0.15 \mathrm{~g}, 0.2,0.25 \mathrm{~g}, 0.3 \mathrm{~g}, 0.35 \mathrm{~g}, 0.4 \mathrm{~g}, 0.45 \mathrm{~g}, 0.5 \mathrm{~g}$ per $100 \mathrm{ml}$ of the sample for a time of 50minutes for size fraction of 300microns.The highest efficiency of nearly $69.8 \%$ was observed for dosage of $0.5 \mathrm{~g}$ per $100 \mathrm{ml}$ of the sample when adsorbent with a size fraction of 300microns was used for a contact time for 50min. Adsorbent dosage of $0.2 \mathrm{~g}$ was considered as optimum dosage since there was not much change observed even after increasing the dosage. 


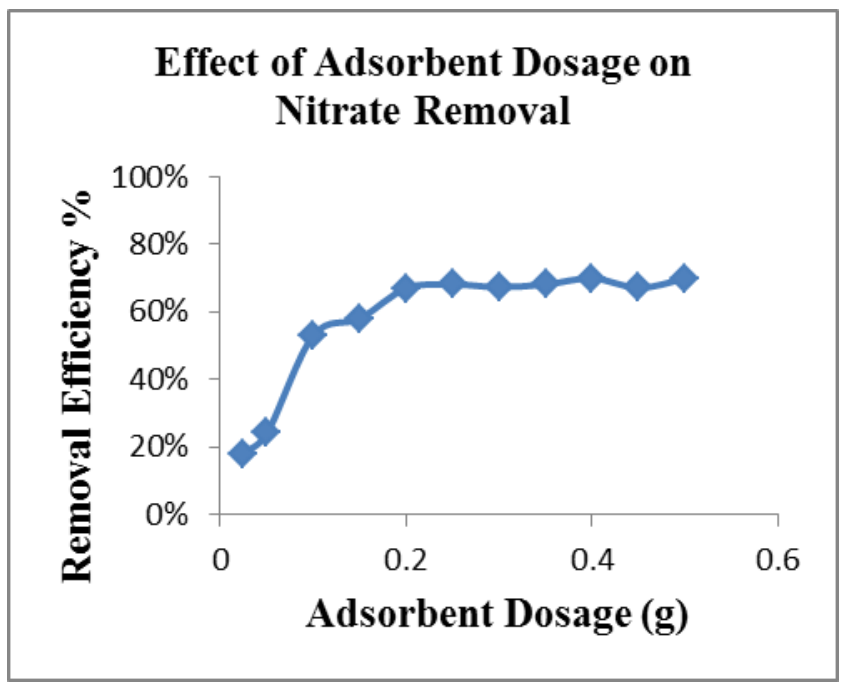

Fig4 Effect of Adsorbent Dosage on Adsorption

\section{CONCLUSION}

Contamination of nitrate in water is a serious issue and emerging technologies are required for removal of it. The present study shows that neem leaves can act as an efficient biosorbent in removal of nitrate from water. The effect of different parameters like contact time adsorbent dosage were studied. Further study of effect of parameters like $\mathrm{pH}$, temperature and effect of different pre-treatment methods of adsorbent would help to increase the efficiency of nitrate removal and enhance the applicability of leaves as a efficient adsorbent.

\section{ACKNOWLEDGMENT}

Authors thank Dr. H.B Raghuvendra, Director, School of Technology, Pandit Deendayal Petroleum University for the encouragements and Guidance, Dr. Debasis Sarkar, Head, Department of Civil Engineering and the other members of the university and family for their support.

\section{REFERENCES}

[1] www.prsindia.org/.../1455682937 Overview\%20of\%20Ground\%2 0Water\%20in $\% 2 \ldots$

[2] NitinMishra, Deepak Khare, K.K. Gupta, Rituraj Shukla (2014)," Impact of Land Use Change on Groundwater - A Review ", Advances in Water Resource and Protection (AWRP) 28(8)

[3] M.C.Limbachiya,K.S.Nimavat,K.B.Vyas,"Physico Chemical Analysis of Ground Water Samples of Bechraji Region of Gujarat State", India Asian Journal of Biochemical and Pharmaceutical Research

[4] www.who.int/water_sanitation_health/dwq/chemicals/nitratenitrite2 ndadd.pdf

[5] Mohammad Hassan Shahmoradi, Behnoush Amin Zade, Ali Torabian and Mahdi Seyed Salehi(2015) "Removal Of Nitrate From Ground Water Using Activated Carbon "Arpn Journal of Engineering and Applied sciences, Volume10. ISSN 1819-6608. 